[Tarr, C. (2007). Early Childhood Education and Care: Learning from Finland. New Zealand Annual Review of Education, 16, 141-150]

\section{Early Childhood Education and Care: Learning from Finland}

\section{COLIN TARR}

\section{Abstract:}

In 2002 a long term strategic plan for New Zealand early childhood education and care (ECEC) provision was announced with three goals, those of increased participation, improved quality and the promotion of collaboration. To realise these goals, New Zealand can learn much from Finland. Finland participated in the Thematic Review of Early Childhood Education and Care Policy project conducted by the Organisation for Economic Co-operation and Development (OECD) in 2000. The purpose of the project was to provide comparative information to help inform ECEC policy-making in OECD countries. This article reviews the OECD report on Finland. An outline of Finnish ECEC provision is briefly described and a brief critique of some Finnish ECEC issues is provided. The article concludes with some comparisons with New Zealand ECEC policy issues.

Fas

nland participated in the Organisation for Economic Co-operation and Development's (OECD) ongoing Thematic Review of Early Childhood Education and Care Policy project initiated in 1998. The purpose of the project was to provide comparative information to help improve policy-making in early childhood education and care (ECEC) in OECD countries. The review team visited Finland in May 2000 and their report was published in 2001.

Finland's education system is highly regarded internationally. Education International (2004) reports an overall $49 \%$ engagement rate in ECEC (peaking at $97.4 \%$ of 6 year olds engaged in ECEC), a primary pupil teacher ratio of 1:18 and a school life expectancy of 15.4 to 16.5 years. Gender parity within the education system, and the country generally, is evident, academic freedom is respected and there are few cases of child labour exploitation (p. 118).

\section{Colin Tarr}

This article provides an overview of the socio-economic/cultural scene in Finland, followed by a brief description of Finnish ECEC provision. The article goes on to provide a short critique of some Finnish ECEC issues and makes some connections and comparisons with recent New Zealand ECEC policy determinations.

\section{Overview}

\section{A description of Finland}

Finland is the seventh largest country in Europe and shares borders with Sweden, Norway and Russia. The country has a land mass of 338,000 sq $\mathrm{km}$ (cf. New Zealand with $270,100 \mathrm{sq} \mathrm{km}$ ) of which $10 \%$ is water, $69 \%$ is forested and approximately $8 \%$ is cultivated land. Its population of 5.2 million consists of $91.51 \%$ Finnish, 5.49\% Swedish, $0.03 \%$ Sami (Lappish), $0.80 \%$ Russian and $2.17 \%$ other nationalities.

Finnish and Swedish are the two national languages with the Sami (indigenous peoples) language spoken by some 1700 out of 7000 Sami living in the north of the country.

Following 1997 reforms, the country was divided into six provinces. Within the provinces are 452 local authorities or municipalities. These municipalities play a key role in education provision and services within their geographical jurisdictions. After a period of economic recession in the early 1990s, Finland "bounced back" and at the time of the 2000 OECD review the country had a robust and steadily growing economy. A relatively low level of unemployment $(8 \%)$ and a relatively high level of overall taxation at $47 \%$ of GDP provide good levels of public monies for investing in education and social welfare services (by way of comparison, New Zealand's tax revenue in 2001 was 32\% of GDP).

Finland is a strong investor in ongoing education. Coughlan (2004) reported the Finnish Education Minister Tuula Haatainen as saying:

In Finland, we believe we have to invest in education, research and in higher education. Education can pioneer new areas for jobs. We

always need new skills for the labour force - so it means that we have to keep investing. (p. 1)

The Finnish Government's objective to be an equitable, motivating, socially sound and undivided state enjoys strong support from its citizens and services. The concept and practice of gender equality is strong in Finland, both in legislation and in long held cultural practices. Finnish women's participation rates in work outside the home have led international comparative tables for decades. A strong appreciation of 
the relationship between child care, the family and the state is well embedded in Finnish policy and practice.

Social services (including education) are a shared responsibility between central government and the municipalities - with central government providing, on average, 24 percent of the funds required for running costs. Indeed, providing for the health, well-being and needs of families is strongly embedded in Finnish social policy. Tax free child allowances are provided for families with children and are paid on a monthly basis.

Since 1990, Finnish families have had the right to a municipal day care place for their child or a home care allowance. An 11 month period of maternity and parental leave is provided as is a monetary allowance for this period based on earned income levels. Following this 11 month period one parent is entitled to childcare leave from his or her work until the child is aged 3. During this time a home care allowance is payable.

Parents can negotiate with their employers for a partial leave provision whereby they can work for reduced hours up to when their child goes to school (at age 7). A taxable allowance is available during this time to supplement the lower income child caring parents would be able to earn, given their reduced hours of paid employment.

Such provisions provide useful examples of how the employment and productivity imperatives of a country can be achieved in tandem with supporting parents in their responsibilities for the care and development of young children.

Indeed in 2005 the Finnish Ministry of Social Affairs and Health said:

The social responsibility of employers should be encouraged in many ways in order to increase respect for family life and boost the potential for family well being. Recognising the needs of the child and of family life is part of good human resource policy. (p. 59)

\section{ECEC policy and provision}

Two government ministries have responsibility for Finnish ECEC - the Ministry of Social Affairs and Health and the Ministry of Education. Agencies within these ministries carry out research, development, curriculum design and evaluation in the fields of education and care. The operationalisation of education and care delivery is managed, and discharged, by the 452 municipalities.

Finnish trade/education unions are recognised as playing a key role in policy development and services and are regarded as partners in these processes by central and local governments. An NGO, the Mannerheim League, is a pioneering child welfare organisation, which operates a local branch structure that provides assistance and support for parents, child and youth. The Finnish Parents Association and the Lutheran Church are also active and engaged in family and social welfare work

There are various types of ECEC provided. Finland describes their system as "educare", suggesting the natural and appropriate blend of education and care. Services include:

\section{- Public day care}

Large numbers of children attend these centres in order to "pick up" their right to free childcare. Public day care is well regarded in Finland because the quality is high. There are stringent regulations defining the physical surroundings, ratios, trained staff requirements, high quality programmes, assessment processes and detailed systems of communication with parents.

- Private day care

This is a small sector, catering for around 3 percent of children under 7 years of age. Private providers work closely with municipalities and are notable for their adherence to quality provision. It is not an unregulated, "for profit" approach that private ECEC provision can be in other jurisdictions.

- Family daycare, group family day care

Care is provided in the home of the provider for up to a maximum of four children under school age. These are supervised by municipalities. The majority of home-based care providers are, in fact, employed by municipalities. Group care arrangements involving up to three childcare providers and 12 children usually operate in facilities provided by the municipality and/or are attached to a day care centre.

- Playgroups and after school care

Playgroups are provided by municipalities, churches and NGOs. These provide a social network for people caring for children at home and usually operate once or twice a week. After school care is provided by churches, social clubs and the voluntary sector. 
Municipalities also arrange for after school care, although provision was significantly reduced during the 1990s economic recession. The OECD reports the provision of after school care falls well short of the demand.

- Pre school education

This refers to the programme provided in the year before Finnish children attend school at age 7 . This voluntary programme (in which some 97 percent of 6 year olds participate) follows a more structured approach to programme content. A policy of 700 hours per year of pre-school education (around 18 hours per week) was introduced in 1999. Pre-school programmes are provided, in the main, by day care centres although it appears likely that new schools in the future will provide facilities for pre-school programmes.

The OECD reports that quality requirements are features "across the board" in terms of Finnish ECEC services. Facilities are of good quality, staff are, generally, well trained and remunerated, ratios are low, programmes are based on "good practice" pedagogy, parental support for services is strong, assessment procedures are sound and constructive partnerships are developed between families and centres. There is flexibility within the provision of "educare" to cater for families' diverse needs. There appears to be careful integration of special needs children into day care environments. There is a commitment to the provision of culturally appropriate services for indigenous (Sami) children and the report describes some beginnings of immersion/language nest approaches to promote first language learning.

Curriculum design and implementation are based on collaboratively developed national guidelines. Aims, methodologies and evaluation processes are then decided at the local level within these guidelines. Preservice teacher education is becoming professionalised with universities providing undergraduate and postgraduate courses. The monitoring and evaluation of ECEC services is based on high trust and utilises a "light touch" approach. Research into ECEC in Finland is strong given the country's preparedness to invest significantly (some 3 percent of GDP) in ongoing research and scholarship. An example of this is the research work undertaken by the University of Jyväskylä Early Childhood Education Department. The department is involved in various national and international projects, many funded by the Academy of Finland. The research activity of the department is described as sociologically oriented, and examines social conditions necessary for children's welfare and agency, and how these can be realised in ECEC and in the wider social context.

\section{A Critique on Some Issues Within Finnish ECEC}

Delors (1998) said:

Early childhood education contributes to equality of opportunity. Apart from the socialisation process that early childhood centres and programmes provide, there is evidence that children who receive early childhood education are more favourably disposed to school. In addition the availability of educational services for young children make it easier for women to participate in social and economic life. (p.

ECEC provision in Finland provides a leading example of what Delors says ECEC can, and does, achieve. In international comparative studies, Finland is an acknowledged world leader in education provision and the OECD report on ECEC policy and provision confirms the strengths there are within the Finnish system. There are, however, some issues worthy of comment and critique.

The "pre-school" education curriculum changes in the late 1990s aligned the programme for 6 year olds with the more formalised approach to learning used in schools. The OECD team weren't overly concerned about this, given the careful and collaborative approaches that were being used to develop curriculum, but they did provide a sensible word of caution that the best of early childhood practice should be considered and reflected in the curriculum developments and pedagogical approaches that take place at this important systemic transition point.

The OECD report noted that the needs and rights of the child to quality education and care - alongside support for families to facilitate parental work - need to be kept in careful balance. Workforce needs, aspirations and engagement can come as a result of quality provision being made for children, but employment and employability shouldn't drive ECEC policy and provision - the needs of children must be at the centre of such decision making.

The child home care allowance provision in Finland is a tangible example of the value the country places on the needs of its young. Interestingly, though, the biggest group taking up the allowance tend to be low income parents with modest educational attainment 
themselves. There is a danger that the allowance could become a substitute salary for the people whose children would gain most from the richness, diversity and benefits engagement in quality early childhood education settings can, and does, provide.

The scarcity of out-of-school care provision was an interesting anomaly when one considers the broad range of Finnish ECEC provided. Given 7 and 8 year old children in Finland finish school at 1pm each day, it would seem the need for some quality "educare" provision during the afternoons is compelling. Whilst there is after-school care provision by church and community groups, public provision of after-school care was scaled back by municipalities during the 1990s economic recession. The OECD report indicates a strong demand for more systemic provision of such "educare".

Given the high level of trust in the education system, centralised accountability and evaluation mechanisms tend to adopt a "light touch" approach. Part of the reason for this high level of confidence comes from the strong research culture in Finland, which provides a rich source of information, analysis and scholarly opinion on educational provision. The OECD team recommended that some thought be given to more robust central agency co-ordination of evaluation and accountability processes to ensure policy development is well informed. However, the demonstrable success of the Finnish system, the high regard it is held in, and the research underpinnings that inform it are the envy of other jurisdictions that are overloaded with "top down" accountability processes that add little value to learning and teaching outcomes. This commentator would urge caution at in troducing external accountability mechanisms unless they clearly added further value to what is already done in Finland.

The final issue for this brief critique of Finnish ECEC issues is that of teacher pre-service and in-service training. Most ECEC workers receive high levels of initial training. There are, however, some groups such as day care assistants where the quality and depth of training provided seems out of step with other parts of the service. This is puzzling, given the strong Finnish commitment to a well educated workforce. A further anomaly is the paucity of in-service training opportunities for serving teachers. Where opportunities are provided it is often at the personal financial cost of the individual teacher in terms of attendance. This is out of character with the rest of Finland's ECEC training commitments when the acknowledged benefits of life-long and ongoing learning are so clearly espoused within Finnish policy and practice.

\section{Connections and Reflections: A Comparison between Finnish and} New Zealand ECEC

In recent years, there have been significant central government development, thinking and announcements regarding New Zealand ECEC policy. This has resulted in a long-awaited ten year strategic plan for ECEC known as Nga Huarahi Arataki: Pathways to the Future (Ministry of Education, 2002). Increasing participation, improving quality and promoting collaboration are the three overarching goals of this well received plan. In giving effect to the practical realisation of these laudable goals, New Zealand can learn much from Finland.

In a review of New Zealand ECEC provision and policy, Dalli and Te One (2002) said:

Equally our review has revealed that challenges remain. These relate to divergent views about the role of the state in the provision of early childhood education services, and to the difficulty of achieving collaboration across a range of services that hold a brief for children. (p. 198)

In Finland the roles of state and local authorities in ECEC provision are clear, unequivocal and enshrined in legislation. The ministries responsible for ECEC (and their agencies) collaborate to provide high quality education and care for Finnish children. A practical example of this is the collaborative development of curriculum guidelines, based on best practice evidence, and then the ability for local people to undertake local interpretation and development of programmes to best meet the particular context and learning needs of the children being served.

Dalli and Te One (2002) argue the New Zealand Government's "Pathways to the Future" statements about universal entitlement to early childhood services suggest it (the government) sees its role as fitting within a social democratic welfare model where entitlements draw on rights of social citizenship (p. 183). Giving effect to this by providing the necessary resources to achieve universal entitlement is the key.

Finland provides an instructive model in this regard. The two ministries responsible for Finnish ECEC are provided with the largest and third largest amounts of "Vote" monies to undertake their work. An array of leave and child-care allowance provisions are provided to support children and their families in order to achieve the right of all Finnish children to have a place within a high quality ECEC programme. This is clearly stated in the 2005 National Finnish Plan of 
Action provided to the United Nations General Assembly Special Session on Children:

Plans for early childhood education and care, school curricula and the whole operating culture in care, upbringing and teaching must offer real chances for children to participate. (p. 64)

The plan calls on education authorities and organisations in Finland to monitor and assess the realisation of participation on a regular basis.

In 2005, the New Zealand Government announced broad policy programmes such as "Working for Families" and "20 hours free child care" and is currently working through the practical arrangements for implementing these. The "proof of the pudding" in terms of how these will practically work to achieve increased participation in quality ECEC provision is yet to be seen.

\section{Summary}

Finland regularly tops the tables of educational performance in international comparative studies. It has an ECEC sector that has within it many best practice elements and approaches. Given this, the argument for adopting and adapting some of the Finnish socioeconomic and socio-cultural policies, practices and approaches in order to enhance the New Zealand ECEC system would seem to be compelling.

\section{References}

Coughlan, S. (2004). Education key to economic survival. Retrieved April 25, 2006 from: <http://newsvote.bbc.co.uk/mpapps/pagetools/ print/news.bbc/co/uk/1/hi/education/4031805.stm >

Dalli, C., \& Te One, S. (2003). Early childhood education in 2002: Pathways to the future. New Zealand Annual Review of Education, 12, 177-202.

Delors, J. (1998). Learning: The treasure within. Report to UNESCO of the International Commission on Education for the Twenty First Century. Paris: UNESCO Publishing.

Education International. (2004). Education is a human right: Barometer of human and trade union rights in the education sector. Brussels: Education International.

Ministry of Education. (2002). Pathways to the Future: A 10 year strategic plan for early childhood education. Wellington: Ministry of Education.
Ministry of Social Affairs and Health. (2005). A Finland fit for children. The National Finnish Plan of Action called for by the Special Session on Children of the UN General Assembly. Retrieved April 21, 2007, from

$<$ www.stm.fi/Resource.phx/publishing/documents/3560/index.htx> Organisation for Economic Co-operation and Development. (2001). Early childhood education and care policy in Finland. Paris: OECD.

\section{The author}

Colin Tarr graduated with a Master of Education degree from the University of Tasmania in 2003. His Masters studies were to do with contemporary educational policy issues and the implementation of change. His recent studies at VUW have been in the fields of early child hood education and care policy and the evaluation of programmes. Colin is a past president of NZEI Te Riu Roa and is the Director of Teacher Education at Te Tari Puna Ora o Aotearoa/New Zealand Childcare Association. 